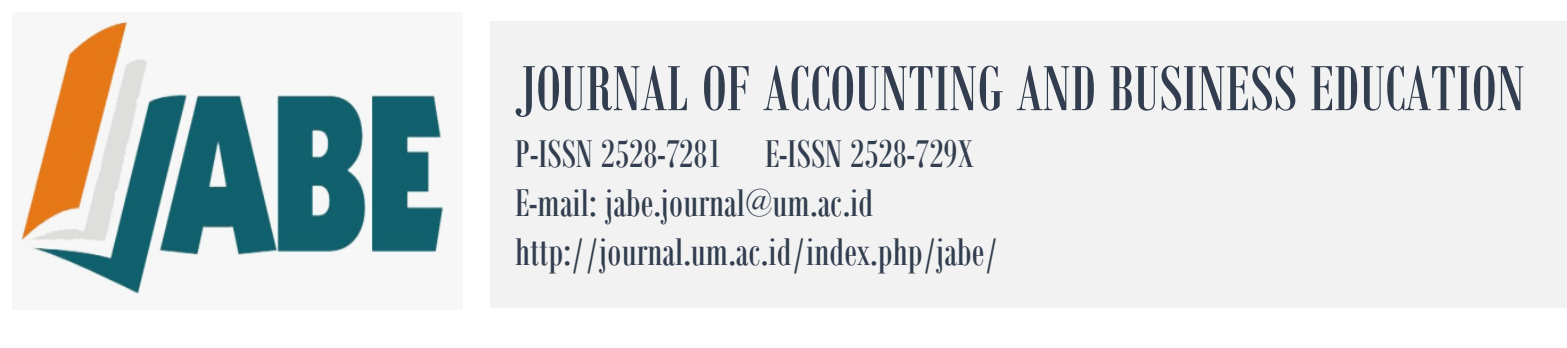

\title{
Improving Motivation and Interpersonal Communication Skill Through Peer Assessment and Self-Assessment In Accounting Education Students
}

\author{
Sulikah \\ Nasikh \\ Universitas Negeri Malang \\ sulikah.fe@um.ac.id \\ nasikh.fe@um.ac.id
}

\begin{abstract}
This study aims at improving motivation and interpersonal communication skill through peer assessment and self-assessment in accounting education students. This study is conducted in Economic Faculty of the State University of Malang (Universitas Negeri Malang). The research subject is 160 undergraduate students of accounting education. This study is a classroom action research. The data collection is done by observation, interview, and documentation. The data are analyzed qualitatively by carrying out data reduction, data display, and verification processes. Research finding shows that peer assessment and self-assessment are able to improve motivation and communication skill of accounting education students in Economic Faculty of the State University of Malang.There is improvement in terms of learning motivation of students majoring accounting education in the teaching practice subject through peer assessment and self-assessment system, and there is improvement in terms of interpersonal communication skill of students majoring accounting education in the teaching practice subject through peer assessment and self-assessment system.
\end{abstract}

Keywords: motivation, interpersonal communication, peer assessment, self-assessment

\section{INTRODUCTION}

In 1990s the National Examination in Indonesia was known as Evaluasi Belajar Tahap Akhir Nasional (EBTANAS) or, literary translated into English, Final Stage of National Learning Evaluation (Abadyo \& Bastari, 2015). The development of science, technology, and communication is getting rapid. The develpoment can become a global world challenge to answer, one of which is by preparing human resources who are able to communicate in the international world (Retnawati, Munadi, \& Al-Zuhdy, 2015). Education master plan is a reference for the education stakeholders to develop educated, knowledgeable, technology literate, and competitive human beings based on the faith to The God Almighty. Beside the Educational Planning arrangement can become the direction for the policy makers and implementation of education in classroom (Nasikh, Ery, Budi, Gatoto, 2015). There is no country which can develop without education. Each country needs to make educational 
changes according to its needs. Through education, people may get knowledge and good behavior which are the best factors leading to the bright life and future. With their knowledge, patriotism, innovations and inventions arise. That is why actually, many governments are doing their best to invest in education, trying to adjust the level of their national education with the standard of the countries who have possessed high standard or best education. They always try to make a new educational program in order to refresh the educational institution in their respective countries according to the world's trend. The Minister of Education and Culture of Indonesia, Mr Nuh announces that 'The future of this nation depends on the new curriculum.' According to his quotation, it is obvious that without changing the education, there will be no progress. Due to that issue, Indonesian government officials, especially those in educational sphere, sat together to elaborate the currently implemented curri- culum, namely Curriculum 2013, and all corresponding teaching/learning materials, its corresponding programs, textbooks, without putting aside how that curriculum is going to be implemented. A curriculum is a vehicle of the govern- ment' needs in all fields if there is something to change or promote, for instance, languages, arts, and sciences. (Irambona, \& Kumaidi, 2015). Motivation is a psychological condition that encourages one to do something. According to Ginting (2008), motivation in learning is something that moves or triggers learners to learn or master materials they are studying. Even, motivation is thought as a vital aspect in education (Noour \& Hubbard, 2015). Various attempts have been done by teachers to grow learners' motivation, because a lot of studies have shown that learners with high motivation tend to achieve great achievement. Okaz (2015) also explains that instructors in university have to think about how to make the learning activity more interactive and motivating.

One of the attempts done by teachers is implementing varied and fun learning method. Assessment as one of learning components should also be varied. During all this time the assessment is mostly administered by teachers, but in the peer assessment and self-assessment learners are involved and given a responsibility to assess their peers and themselves. By involving learners in the assessment process, it is expected that they can grow motivation in the learning activity.

Communication skill is a proficiency, skill, or ability to communicate. Communication is a key for a successful interaction and career, because a successful relationship is built and constructed by a good communication. In line with 2013 curricula, the learning process is expected to be conducted through a scientific approach, in which one of the skills developed is the skill to communicate the obtained knowledge. Peer assessment and self-assessment give an opportunity to learners to express their assessment result to their friends and themselves by 
using an effective language. By applying this assessment system, learners are accustomed to convey messages or communicate with their teachers or friends.

Accounting education study program is a study program that produces accounting teachers in the future. Teachers play a significant role to achieve the education purposes. They also give big impacts to the education output. According to Anderson \& Anderson, (1982), developing effective peer and self-assessment takes time and effort. However once fully embedded in learning and teaching, these assessment strategies can be particularly effective in motivating learning. An effective starting point is for teachers to model the process of peer assessment and feedback, for example how to give feedback that is constructive, detailed, linked to assessment criteria, objective, focused etc.

According to Anderson \& Anderson, (1982), teachers' quality is considered one of the most important factors affecting students' achievement. There are four competences teachers have to master; one of them is a social competence. The social competence is an ability to build a relationship and communicate well with the surrounding they are in. The social competence is obtained by teachers when they are studying in the university. It is strengthened by activities outside the class. For teacher candidates, the learning model in the university has to be able to inspire them to teach professionally at school (Reid, Petocs, \& Gordon, 2010). Therefore, the learning activity in the university including its assessment element should be able to support the process of producing professional teachers.

A change in the education paradigm from the teacher-centered to the student-centered brings a consequence that learners are involved in the assessment process (Sutrisno, 2012). The learning evaluation method that can actively involve learners is peer assessment and selfassessment. This assessment system is used to measure the cognitive and non-cognitive skill of learners. Chaney \& Ingraham (2009) state that peer assessment is an effective method to improve the quality of learners' learning process. Learners will be more motivated if the feel they are "monitored" or "assessed" by their peers. Previous studies prove that learners tend to listen to their peer's comments rather than their professor's (Hirsch and Gabriel, 1995). Even, the well-built and well-applied peer assessment will be able to improve learners' cognitive and social skills which make them successfully interact with other people in the daily life (Rochmiyati, 2013).

Despite the advantage and support for peer assessment and self-assessment, the two assessments are rarely applied in the teaching practice (Birjandi \& Siyyari, 2010). In the real learning activity, teachers mostly do the assessment and learners are less involved. Teachers assume that learners have insufficient skill to assess others. Teachers have no clear and 
standardized assessment criteria. In addition, another issue rising from the assessment system is the validity and reliability problems.

This study aims at improving motivation and communication skill through peer assessment and self-assessment in accounting education students. The assessment system is expected to be able to improve learners' participation and activeness in the learning activity, so they are more motivated. Furthermore, it is expected that the assessment system will foster their communication skill because teacher candidates are required to master the skill. It is expected that teacher candidates will always maintain good communication with their students, colleagues, or their surroundings. The good interpersonal skill will be able to make them survive in the society.

\section{REVIEW OF LITERATURE}

An intrinsic motivation is an encouragement that comes from within oneself. One of the examples is a university student who takes part actively in the learning process by expressing comments, ideas, or answers towards issues, questions, or comments given by other students or lecturers. Twigg (2003) in Goldsworthy and Rankine (2009) explains that university students not only obtain help from their lecturer, but also get assistance from their peers. It makes them feel that they are the part of learning community. This feeling is a motivation for them as it fulfills their self-existence to learn and feel satisfied. Nielson and Bryant (2005) adds that an extrinsic motivation coming from lecturers and friends' empathy can give a learning comfort. They also explain that learners will have higher motivation when they believe that their lecturer pays attention to their learning process. The increased motivation will eventually improve their performance.

Communication is an exchange of message verbally and non-verbally from the sender to receiver which aims at behavior changing (Muhammad, 2005). Meanwhile, the interpersonal communication is a communication done by two people who have interpersonal relationship (De Vito, 1995). The interpersonal communication usually involves two or more people as the communicator and communicant. This kind of communication is not only oneway, but also two-ways (Walgito, 2001).

De Vito (1995) sees the effective interpersonal communication based on the humanistic model (soft approach) and pragmatic model (behavioral). The pragmatic model (behavioral) that is also known as the hard approach focuses on particular behavior that has to be acted by the interpersonal communication doer if they want an effective communication. This approach proposes five skills that have to be mastered, namely confidence means that 
the interpersonal communication doer has to possess social confidence. A socially confident communicator will communicate in relax and comfortable ways and they are able to control their body language. They are also neither nervous nor shy. This quality helps other people be more comfortable; immediacy refers to a situation of togetherness between the speaker and listener (oneness). Immediacy is shown by attention and interest. The immediacy can be displayed verbally or non-verbally; interaction management is an ability to control the interaction so that both communication parties are satisfied. It is shown by managing the turn to talk, managing to talk smoothly, and delivering the message consistently. Both parties have to do self-monitoring appropriately; expressiveness refers to an ability to seriously involve in the communication process. It also includes the responsibility to what is said and thought, how to stimulate other party to be open, and how to give an appropriate feedback; other orientation includes an ability to adapt to other people during the interpersonal communication process. It also refers to paying attention and showing interest to other party. It can be demonstrated verbally or non-verbally.

According to Boud (1991) self-assessment is defined as learners' involvement to identify the criteria or standard applied in the learning activity as well as makes decision about the criteria and standard achievement. Meanwhile, peer assessment refers to a process in which a learner assesses other students who are in the same level. The same level means two or more learners are in the same class level or the same subject.

Peer assessment and self-assessment are basic principles of the active learning (Falchikov and Goldfinch, 2000). These two concepts are not merely distributing assessment rubric to learners in order to implement the open and transparent assessment system. It also trains learners to be realistic to decide what score is worth their attempt in the class (Thomas, Martin, \& Pleasant, 2011). In addition, peer assessment and self-assessment help learners get more appropriate feedback, so they know to what extend their material mastery and application are (Siswaningsih, et al, 2013).

Peer assessment and self-assessment are independent learning forms that are useful to support learners' success in campus and professional career (Thomas, Martin, \& Pleasant, 2011). Willey \& Freeman (2006) explain some advantages of peer assessment. They are as follows to force learners to act as assessors who understand the learning process; to improve learners' understanding about the importance of assessment; to increase learners' learning motivation; to build learners' professional skill, such as how to reflect and how to think critically. 
Research finding by Chaney \& Ingraham (2009) reveals that learners are able to improve their skill in terms of case analysis after applying peer assessment and selfassessment. The analytical skill is better due to the fact that learners' accountability increases as they feel their assignments are scored by their peers. The analytical skill improvement is also caused by the higher quality of assignment done by the learners after they have been evaluated by their peers, because they have to follow their friends' standard that is likely to be higher than theirs.

Kennedy in Rochmiyati (2013) points out some issues encountered in the peer assessment application. Learners might be less consistent in doing the assessment. In addition, particular learners are worried of making mistakes, so they cannot assess freely. Peer assessment can also cause a conflict among learners resulting in the decreased group's cooperation and performance. Last but not least, peer assessment can make gaps of learners' rank.

Karami \& Rezaei (2015) explain that the effectiveness of peer assessment highly depends on several factors, such as learners' behavior, learners' mastery towards the assessment criteria, the assessed factor, and biased assessment due to the friendship and gender difference factors. This explanation is in line with the statement by Landry, Jacobs, \& Newton (2015). They argue that peer assessment cannot be positively and consistently expected because the assessment is fully conducted by learners. There is a possibility that learners give poor assessment to friends they do not like, and they give best score to those they like despite the fact that their assessment is not consistent to their friends' performances. As a result, repeated assessment has to be administered in order to obtain more accurate and more similar result to the lecturer's assessment.

To implement well-applied peer assessment and self-assessment, an educator is required to prepare a clear syllabus that contains learning purposes and targets each individual has to achieve (Reese-Durham, 2005). The assessment can be done by using rubrics containing the important aspects of assessment.

Siswaningsih, Dwiyanti, \& Gumilar (2013) have conducted a study of Applying Peer Assessment and Self-Assessment in Hydrocarbon Formative Test to Tenth Graders' Feedback. In the study, they conducted six learning stages, namely motivating students, practicing peer assessment and self-assessment, administering formative test and giving feedback, conducting peer assessment, carrying out self-assessment and giving feedback, communicating the result, and utilizing the result. 
More clearly, Thomas, Martin, \& Pleasant (2011) explain three strategies used to improve the quality of peer assessment and self-assessment. They are modeling, scaffolding, and fading. Modeling is a strategy in which the educator gives example of how to assess to guarantee the score reliability and accuracy. The second step is done by building structured assessment scheme, such as assessment rubric. The more learners practice doing peer assessment and self-assessment, the more positive their attitudes are towards this assessment system. In this stage, the educator can monitor less strictly and learners can do the assessment independently.

There are some problems that inhibit the success of peer assessment and selfassessment implementation. Thomas, Martin, \& Pleasant (2011) cite previous studies revealing that peer assessment and self-assessment will not be successful if learners are not well-supervised, learners are burdened by the system, and teachers and learners are subjective when doing the assessment. Peer assessment and self-assessment will not be effectively implemented if the criteria used to in the assessment are not proven for its validity and reliability (Hancock, Dale-Jones, \& Willey, 2013). Each self and peer assessment exercise involves students assessing their contribution and that of their members to areas of the project specified by criteria. These criteria relate to both the discipline / technical requirements of the activities and how students contributed using their class and competency skills

\section{METHODS}

In the first semester 2017 a post-subject survey was conducted to assess the effectiveness of the self and peer assessment processes used in the subject Design Fundamentals This study is a classroom action research intended to improve the learning quality in the class. The classroom action research used in this study consists of two cycles. The research plan is adapted from Kemmis Altrichter and McTaggart (2002) consisting of four stages in each cycle, namely planning, implementing, observing, and reflecting. The research subject of this study is 160 students majoring accounting education in Economic Faculty of the State University of Malang. Data and data source are obtained by the researcher during peer teaching subject and from students. Data are obtained by using several techniques, namely interview, observation, and documentation. Action research, involving overlapping cycles of planning, acting and observing, and reflecting. It was utilised to maintain a responsive study design. Data collection and analysis were combined and used to shape ongoing data gathering in order to develop a participative-assessment procedure responsive to student priorities and concerns. The study design drew on literature in the area 
of peer assessment and classroom action research, incorporating numerous elements deemed important including; assessment of process rather than learning outcomes; use of assessment criteria targeting five significant areas of performance; including assessment of participation; use of multiple specific criteria on the assessment instrument, targeting discrete areas of student performance rather than a few global indicators (Tracey, Louise, and Michele, 2005). Data analysis is done by using qualitative approach consisting of data reduction, data display, and data verification.

\section{RESULTS AND DISCUSSION}

In the first cycle, the researcher carried out four activities, namely planning, implementing, observing, and reflecting. In the planning stage, the researcher prepared the learning stuff, such as syllabus, suitable learning source and media, assessment instrument, scoring criteria, and observation sheet as well as interview guide.

In the implementing stage, the researcher explained the study contract and syllabus as the learning guidance for one semester. In this stage, the researcher also told the students about the expected competence. Another thing to do in this stage was explaining to the student that it was a teaching practice and practice to create good accounting lesson plans for Vocational School. After that, the researcher determined the teaching practice turn and created lesson plans. The assessment component in this lecture was teaching practice assessment, lesson plan assessment, and behavior assessment during the lecture. The scoring system in the lecture consisted of $50 \%$ of lecturer assessment, $20 \%$ of peer assessment, and $20 \%$ of self-assessment. Each student did at least two teaching practices in 30 minutes each. When the students were doing their teaching practice, a camera was put to record their activities. After the class, the students had to copy the video file. The students watched their own performance and assessed as well as evaluated themselves by filling in the available format. The peer and lecturer assessments were done during the teaching practice by filling in the observation and assessment sheets. Before doing the assessment, the researcher explained the assessment rule and scoring range, so there was similar perception about the assessment among the students. Every student would be assessed by two observers.

During the process, the researcher observed the students' behavior. This activity aimed at identifying the student's motivation level when joining the class and improving the next lecturing system.

In the reflecting stage, the researcher analyzed and evaluated the observation result so that she could identify the follow-up activity. If there was no optimal result in this cycle, 
improvement had to be carried out in the next cycle. In this stage, the researcher also did reflection with other observers to identify the effect of assessment system to the student's motivation.

Furthermore, Cycle Two consisted of four stages, namely planning, implementing, observing, and reflecting. According to the result of Cycle One, a change was done: the researcher determined the basic competence in the teaching practice. Previously, the student chose the basic competence themselves and they tended to choose the same competence, so they were bored during the teaching practice. In addition, there was a change in scoring that used Likert Scale. Implementing, observing, and reflecting stages in this cycle were the same as Cycle One. Reflecting stage in this cycle was done to identify the difference between Cycle One and Two in terms of result. In Cycle Two, there was improvement in terms of student's motivation and communication skill. Therefore, the cycle would not need to be repeated. The quality of education is determined by three components, namely: input, process, and output. Among those three components, the education process is one of the most decisive components in improving the quality of education. Therefore, the education process has to be the concern of the stakeholders who are responsible for improving the quality of education (Nasikh, Ery, Budi, Gatot, 2015). The problems in educational services in classroom are mostly on the low quality of human resources and unfulfilled needs of students' competences. This is because of the low quality of teachers and lack of learning facilities. The gap in equality and extension of opportunity to have education not only caused by the geographic factor, but also economic factor. Standard of education financing is one of the decisive aspects to create qualified graduates in every educational institution. The standard refers to Regulation of the Minister of National Education of the Republic of Indonesia No.19 Year 2007 on the Management Standards of Primary and Secondary Education. It is said the financing standard is a standard, which regulates components and costs of educational operation within a year (Nasikh, Ery, Budi, Gatot, 2015). Motivation was measured by using indicators developed by Astira, et al (2013). They included students' interest and attention to the lesson; students' spirit to accomplish the task,; students' responsibility to accomplish the task; students' reaction towards stimulus done by the lecturer, and students' satisfaction when accomplishing the task.

The observation result in Cycle One showed that the mean score of students' motivation was 65 , but it reached 78 in Cycle Two. It showed that there was motivation improvement from Cycle One to Cycle Two. It was shown from better discipline, increased frequency of discussion about the task given by the lecturer, as well as better quality of lesson 
plan and teaching practice. In addition, the students were more enthusiastic in following the lesson and they were actively involved. They felt more satisfied because they obtained direct feedback related to their performance and they got to know their strength and weakness. It was in line with the research finding of Willey and Freeman (2006) explaining that peer assessment could improve students' learning motivation. Peer assessment and self-assessment caused the students to have responsibility to assess and communicate the result to their peers. The assessed student would be more motivated because they were well-monitored by peers and lecturer.

The students' interpersonal communication skill was measured by soft approach and hard approach consisting of ten indicators (De Vito, 1995). The individual education implanted in the family to make one active, persevering, courageous, smart, alert, clear in thinking, and caring is reinforced by religion education at school. Likewise, social education habitually practiced in the family to make one frugal, dislike vain deeds or conditions, give help easily, and have empathy to someone suffering is also reinforced by religion education in school. Education of the family model works in synergy with education of the school model (Syamsudin, Budiyono \& Sutrisno, 2016). The research finding showed that peer assessment and self-assessments were able to improve the interpersonal communication skill of accounting students. This was similar to the finding by Rochmiyati (2013) revealing that peer assessment could improve the students' social skill which required the students to build good cooperation and communication. Through this system, the students would be able to obtain direct feedback which encouraged them to improve sustainably. This system required the students to be able to communicate their assessment result by using appropriate, communicative language objectively.

Another finding showed that there was improvement in terms of students' interpersonal communication skill. It was shown from the increased score for each indicator. The students were more open and honest to express their peers' strength and weakness. The assessed student had the chance to confirm the assessment directly, thus, there was openness in their communication. In addition, the students would get accustomed to be able to comment and give suggestion to each other freely.

Peer assessment and self-assessment would train the students to organize their empathy and emotion when communicating. They would get used to choose the communicative language to convey an intended meaning to their peer. The purpose of communication was achieved without hurting the partner. The students could develop positive thinking to accept suggestion from peers and attempt to improve in the future time. 


\section{CONCLUSION}

According to the finding, it can be concluded that (1) there is improvement in terms of learning motivation of students majoring accounting education in the teaching practice subject through peer assessment and self-assessment system, and (2) there is improvement in terms of interpersonal communication skill of students majoring accounting education in the teaching practice subject through peer assessment and self-assessment system. The results scoring in this study consisted of $50 \%$ of lecturer assessment, $20 \%$ of peer assessment, and $20 \%$ of self-assessment.

Based on the discussion and conclusion, it is suggested that (1) before implementing the assessment system the lecturer has to explain about the assessment component and scoring system clearly so that every student has the same perception, (2) feedback has to be responded by the student by making a room of improvement that will be assessed by the lecturer, (3) observer or peer assessor is chosen by the lecturer to strengthen the objectivity, and (4) there is an obligation for all observers to express their assessment directly.

\section{REFERENCES}

Abadyo, A., \& Bastari, B. (2015). Estimation of ability and item parameters in mathematics testing by using the combination of 3PLM/GRM and MCM/GPCM scoring model. REiD (Research and Evaluation in Education), 1(1), 55-72.

Altrichter, Kemmis, McTaggart, and Skerritt. 2002. The Concept of Action Research. The Learning Organization (Online), (http://www.google.co.id) Acces 3th February 2018

Anderson, L. W. \& Anderson, J. C. (1982). Affective assessment is necessary and posible. Educational Leadership, April, 524-525.

Birjandi, P., \& Siyyari, M. (2010). Self-assessment and peer-assessment: A comparative study of their effect on writing performance and rating accuracy. Iranian Journal of Applied Linguistics.

Boud, D., \& Falchikov, N. (1991).Quantitative studies of student self-assessment in higher education: A critical analysis of findings. Higher Education

Chaney, B. A., \& Ingraham, L. R. (2009). Using peer grading and proofreading to ratchet student expectations in preparing accounting cases. American Journal of Business Education.

De Vito, J. A. 1995. The Interpersonal Communication. Seventh Edition. New York: Harper Collins College Publisher.

Falchikov, N., \& Goldfinch, J. (2000). Student Peer assessment in higher education : a meta 
analysis comparing peer and teacher marks. Review of Educational Research.

Gintings, Abdorrakhman. 2008. Learn and Learning. Bandung: Humaniora

Goldsworthy, Kathie \& Rankine, Lynnae. 2009. Identifying the Characteristics of E-Learning Environments Used to Support Large Units. Proceeding Ascilet Auckland. Hooker, Mary. Models and Best Practices in Teacher Professional Development Education Specialist.http://www.glp.net/home Acces 28 March 2018.

Hancock, P., Dale-Jones, G., \& Willey, K. (2013). Impact of collaborative peer and self assessment on students' judgment and written communication. Teaching \& Learning Forum.

Hirsch, M. L. \& Gabriel, S. L. (1995). Feedback strategies: Critique and evaluation of oral and written assignments. Journal of Accounting Education.

Karami, A., \& Rezaei, A. (2015). An overview of peer-assessment: The benefits and importance. Journal for the Study of English Linguistics, 3 (1), 93-100

Landry, A., Jacobs, S., \& Newton, G. (2015). Effective use of peer assessment in a graduate level writing assignment: A case study. International Journal of Higher Education, 4 (1), $38-52$

Muhammad, Arni. (2005). Organization Communication. Jakarta. Publisher: Bumi Aksara.

Nasikh , Ery Tri Djatmika RWW, Budi Eko Soetjipto, Gatot Isnani (2015). A Model of Affordable and High Quality Education Policy in Tulungagung Regency East Java Indonesia. International Journal of Business and Management ISSN 1833-3850 $\begin{array}{llllllll}\text { (Print) } & \text { ISSN } & \text { 1833-8119 (Online). } & \text { Vol } & 10 & \text { No } & 10 & \text { (2015), 263-268. }\end{array}$ http://www.ccsenet.org/journal/index.php/ijbm/article/view/52188/28593

Nielson, Kristy A. and Bryant, Ted (2005). The effects of non-contingent extrinsic and intrinsic rewards on memory consolidation. Journal of Neurobiology of Learning and Memory. Volume 84, Issue 1, July 2005, Pages 42-48. https://doi.org/10.1016/j.nlm.2005.03.004

Noour, Aisha Tarek \& Hubbard, Nick. 2015. Self-Determination Theory: Opportunities and Challenges for Blended e-Learning in Motivating Egyptian Learners. Procedia - Social and Behavioral Sciences 182: p. 513 - 521

O'Connor, A Katherine; Greene, H Carol; Anderson, Patricia J. 2010. Action Research: $A$ Tool Foor Improving Teacher Quality and Classroom practice. This papers presented the Annual Meeting of the American Educational Research Association (San Francisco, CA, Apr 7, 2006) 
Okaz, Abeer Ali. 2015. Integrating Blended Learning in Higher Education. Procedia - Social and Behavioral Sciences 186 ( 2015 ) $600-603$

Reese-Durham, N. (2005). Peer evaluation as an active learning technique. Journal of Instructional Technology, 32, 338-346

Reid, Anna; Petocz, Peter; \& Gordon Sue. 2010. University Teacher's Intentions for Introductory Professional Classes. Journal of Workplace Learning. Vol. 22 pp. 67-7

Retnawati, H., Munadi, S., \& Al-Zuhdy, Y. A. (2015). Factor analysis to identify the dimension of Test of English Proficiency (TOEP) in the listening section. REiD (Research and Evaluation in Education), 1(1), 45-54. https://doi.org/10.21831/reid.v1i1.4897

Rochmiyati. (2013). Peer Assessment Model in the Elaborative Collaborative Learning of Integrated Social Science in Junior High School. Education Research and Evaluation Journal, 17 (2), 333-346.

Siswaningsih, W., Dwiyanti, G., \& Gumilar, C. (2013). Implementing Peer and Assessment and Self-Assessment in the Hydrocarbon Test for Tenth Graders' Feedback. Chemistry Education Department FPMIPA, 18(1), 107-115.

Sutrisno. (2012). Learning Fluid by Using Jigsaw Method with Peer Assessment to Foster Activities, Scientific Behavior, and Achievement of XI IPA Students. Journal of Innovative Science Education. : http://journal.unnes.ac.id/sju/index.php/jise retrieved on 10 February 2018

Syamsudin, A., Budiyono, B., \& Sutrisno, S. (2016). Model of affective assessment of primary school students. REiD (Research and Evaluation in Education), 2(1), 25-41. https://doi.org/10.21831/reid.v2i1.8307

Thomas, G., Martin, D., \& Pleasant, K. (2011). Using self- and peer-assessment to enhance students' future-learning in higher education. Journal of University Teaching \& Learning Practice, 8(1), 1-17.

Tracey papinczak, Louise young and Michele groves. (2005). Advances in Health Sciences Education (2005) 12:169-186. Springer. 2005. DOI 10.1007/s10459-005-5046-6

Twigg, A. Carol. 2003. New Models for Online Learning. Educause September/October 2003 Walgito, B. 2001. Social Psychology: An Introduction. Yogyakarta: Andi Offset.

Willey, K. \& Freeman, M. (2006). Improving teamwork and engagement: The case for self and peer assessment. Australasian Journal of Engineering Education. http://www.aaee.com.au/journal/2006/willey0106.pdf 